Article

\title{
Human-Nature for Climate Action: Nature-Based Solutions for Urban Sustainability
}

\author{
Helen Santiago Fink \\ Department of Landscape, Spatial and Infrastructure Sciences, University of Natural Resources and Life \\ Sciences, Vienna 1180, Austria; hsfwien@yahoo.com \\ Academic Editor: Tan Yigitcanlar \\ Received: 18 December 2015; Accepted: 1 March 2016; Published: 15 March 2016
}

\begin{abstract}
The global climate change agenda proceeds at an incremental pace while the Earth is approaching critical tipping points in its development trajectory. Climate action at this pinnacle juncture needs to be greatly accelerated and rooted in the fundamentals of the problem-human beings' disconnection from nature. This paper underscores the valuable role nature and nature-based solutions can play in addressing climate change at the city scale and its implications for broader sustainability. Urban ecosystems (nature in cities) are seen as an integral part of a proposed local climate action rubric wherein policy measures and integrated planning guide lowcarbon/impact development to create more resilient and sustainable urban environments. The use of green infrastructure is highlighted as a cost-effective means to contribute to mitigation and adaptation needs as well as to promote human wellbeing. The paper takes an exploratory view of the influence of ecosystem services, particularly cultural services, and its economics in relation to the individual and society to understand how biophilia can be nurtured to promote environmental stewardship and climate action.
\end{abstract}

Keywords: cities; climate change; nature; urban ecosystem services; green infrastructure; sustainability; behavior change; biophilia

\section{Introduction: A New Local Climate Action Rubric}

"We should bear in mind that profound changes in attitudes, behaviours and policies will be required to create a world in which human beings live in harmony with nature." Sam Kahamba Kutesa, UN General Assembly President—Dialogue on Harmony with Nature (UN News 2015 [1]).

It is time to move beyond process to tangible action at multiple scales to avoid the impending climatic and socio-economic tipping points confronting human existence. It is imperative we strike an equilibrium between humans and nature in light of growing populations, accelerating consumption, exploitative resource extraction and deteriorating biodiversity, being keenly aware that humans are dependent on the natural environmental for survival and not the inverse.

The sustainability of human development is grounded in attaining a social-ecological balance and harmonious quality of life with nature. Accelerating societal understanding of the inherent dependency human beings have on the natural environment for human health, economic development and societal evolution is fundamental to foster respect and accountability toMother Earth. Once understood, nature can be our salvation and the innovation of the future.

Nature-based solutions to our climate dilemma also lay the foundations for sustainable development and human wellbeing. The European Commission defines "nature-based solutions" "as actions which are inspired by, supported by or copied from nature". Clearly, multidisciplinary approaches to the climate challenge also need to include disinvestment from fossil fuel energy, building local capacities, employing more women decision-makers, citizen engagement, green production and integrated urban planning to reduce dependency on motorized transport. Women comprise only seven percent of environment, natural resources and energy ministers and a mere three percent of science and technology ministers 
globally. Yet, research indicates when women are in leadership positions in greater numbers, public and collective issues are more often prioritized, including access to clean water and education and setting aside protected land areas as well as conflict prevention and sustainable peace solutions being more common (UN 2012 [2]). Sustained climate solutions warrant a paradigm re-think in how the developed countries pursue economic growth and value quality of life, with developing and emerging economies avoiding the mistakes of the former. Decoupling economic growth from environmental degradation is essential to keep within planetary resource boundaries, with city-level decoupling increasingly essential in light of growing urbanization (UNEP 2013 [3]).

The paper puts forth a nature-based approach in the context of a local climate action rubric, wherein the drivers of a sustainable and resilient city include: (1) policy incentives and integrated systems planning; (2) rich biodiversity and natural ecosystems; and (3) low carbon urban infrastructure and green infrastructure (see Figure 1). The valuable contribution of cities to the global climate agenda is underscored, emphasizing the potential of the local context to change behavior towards climate action and global sustainability. The economics of nature are outlined to make the business case for greater use of nature-based solutions in our cities and built environments to positively exploit the ecosystem services for climate mitigation and adaptation as well as resource efficiency. The important contribution of green infrastructure to sustainable urban development is reviewed, particularly in support of urban ecosystems services and quality of life.

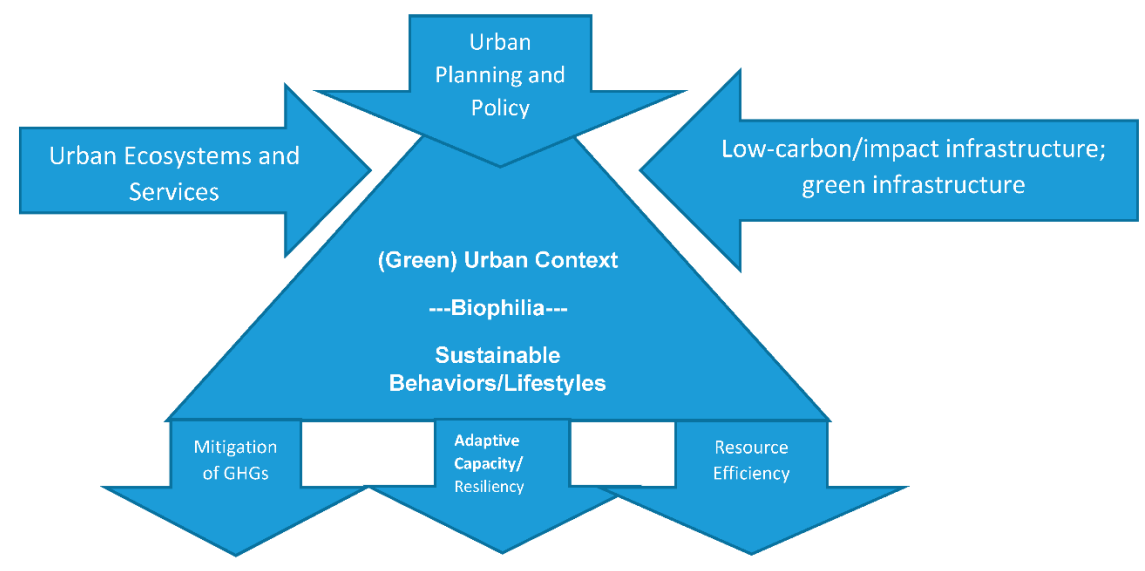

Figure 1. Conceptual framework: local climate action rubric (source: author).

The paper also explores biophilia in the social-ecological context to make a case for its role in environmental stewardship and support of climate action. Climate action (or sustainable behavior) for the purpose of this paper is defined as any action that reduces or supports emission reductions of carbon and/or greenhouse gases (GHGs) as well as enhances the adaptive capacity of built environments, populations groups, and communities to sustain climatic shocks. Accomplished sustainable policy measures and initiatives are outlined for governments and research recommendations are proposed for further investigation.

\section{The Role of Cities in Advancing Climate Action}

Global human population is forecasted to reach nine billion by 2050 , of which $70 \%$ will be residing in urban environments. This trend, in and of itself, is a fundamental driver and multiplier of human behaviors compounding the precarious climate change reality. A growing middle class, accelerating consumerism and expanding urbanization are in juxtaposition to increased natural resource demand, declining biodiversity and jeopardized public health.

Cities are well positioned to play an instrumental role in combatting the localized impacts of climate change and significantly contribute to the global climate commitments. Cities can directly effectuate change through greater engagement in peoples' daily lives with an inherent understanding 
of the socio-economic conditions and local vulnerabilities. Municipal responsibilities over key sectors, including land use planning, buildings, urban infrastructure and services and local ecosystems can influence lower emission trajectories and strengthen adaptive capacities, creating an urban context and the choice architecture that can encourage human behavior towards sustainable actions and lifestyles-ultimately the game changer in the climate agenda.

The UN Climate Summit in September 2014 affirmed the critical role of cities and their significant GHGs reductions (8.0 $\mathrm{Gt} \mathrm{CO}_{2 \mathrm{e}}$ ) possible by 2050 (Figure 2). These contributions come from three core sectors, buildings, transport and waste; however, as illustrated below the emissions gap remains critical and warrants additional aggressive (urban) action and commitments as recommended in this paper to remain within the global carbon budget of $1000 \mathrm{Gt} \mathrm{CO}_{2}$ and the $2 / 1.5^{\circ} \mathrm{C}$ tipping point (Erickson and Tempest, 2015 [4]).

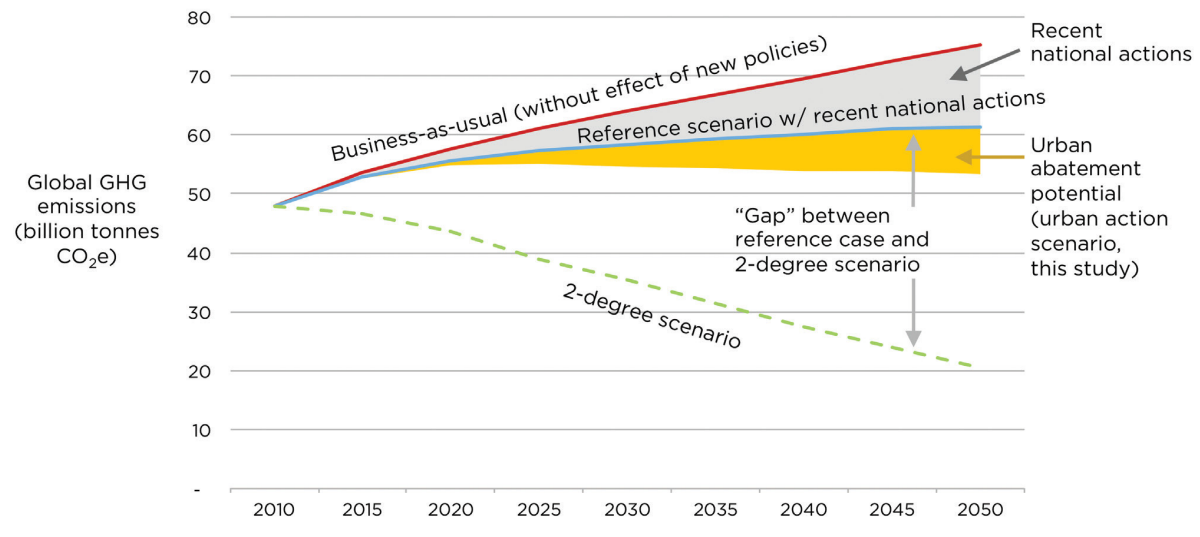

Figure 2. Potential Urban Emissions Impact (Source: SEI/C40 2014, [5]).

The building sector remains the low hanging fruit for reducing urban and global emissions (IPCC 2014 [6], Santiago Fink 2011 [7]). The rate and amount of construction, particularly in emerging markets and developing countries presents a unique opportunity for cities to ensure the built environment is low orcarbon neutral and contributes to the reduction in urban building GHG emissions targets of $2.4 \mathrm{GtCO}_{2 \mathrm{e}}$ in 2030 and $4.5 \mathrm{GtCO}_{2 \mathrm{e}}$ in 2050 (Erickson and Tempest, 2014 [8]). Emissions reductions in the sector can be further expanded with sustainable design and green infrastructure applications, e.g., green roofs, to complement smart technologies supporting energy efficiency and enhanced systems performance. New York City has committed to this path in its PlaNYC/One NYC, forecasting a 30\% reduction in GHG from retrofitting buildings for greater energy performance by 2025 coupled by significant green jobs growth (Figure 3), and is an illustrative model for other cities and their potential impact.

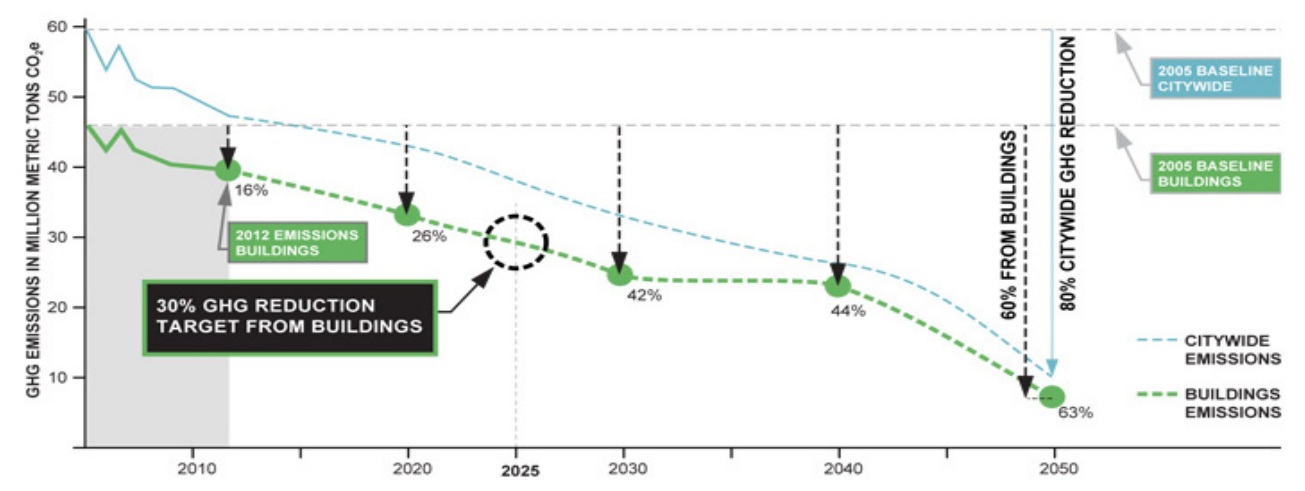

Figure 3. NYC Building Greenhouse Gases GHG Reductions (source: http:/ /www.nyc.gov/html/ builttolast/pages/plan/plan.shtml [9]). 
The building sector can also guide local resiliency by ensuring the siting of structures is not prone to climatic hazards and support principles of environmental justice. Structural change through urban planning and low-impact infrastructure development can deepen emissions levels (IPCC Synthesis Report 2014, Erickson and Tempest, 2015 [4,6]) and when complemented with green infrastructure and other natural design applications offer opportunities for broader social and physical resiliency. Washington, DC (WDC) strongly advocates green roofs for storm water management and to support energy conservation, evidenced by its 2015 inventory of over five million square feet, the equivalent of 58 acres (23.4 hectares). On average, a green roof in WDC retains 15 gallons (56.7 liters) of storm-water per one square foot ( 0.09 square meter) of coverage or $50 \%-75 \%$ of rainfall on an annual basis (Chesapeake Bay Foundation, 2008 [10]).

Urban development patterns and transportation networks lay the foundation for urban sustainability or conversely the prolonged lock-in of carbon intensive trajectories. Sustainable urban form has the potential to mitigate $20 \%$ of future carbon emissions compared to the BAU scenario between 2015 and 2030 (Erickson and Tempest, 2015 [4]). Cities can thrive when land use in the central business district (CBD) prioritizes housing and businesses rather than parking. In the USA on average $80 \%$ of CBD land area is used for parking (Manville and Shoup, 2004 [11]), with the average car being parked $96 \%$ of the time (Heck, Rogers and Carroll, 2014 [12]). Cities with the enabling environment both in the form of policy incentives and low carbon or carbon neutral urban infrastructure are better placed to guide their citizenry towards sustainable behaviors and to help stem the anthropogenic impact on the natural environment.

\section{Importance of Urban Ecosystem Services}

Cities benefit from valuable ecosystems services and can be rich in biodiversity (Beatley, 2011 [13]). The multi-functionality of natural systems supports the triad of sustainability and demands of climate change both to mitigate GHG emissions and enhance adaptive capacities making them among the most cost effective solutions for climate challenges at the local scale (McPhearson et al., submitted [14]). As the world becomes more urbanized, urban ecosystems will be all the more important to protect population agglomerations and critical infrastructure as well as connect human beings with the natural environment to cultivate attitudes and foster social norms towards nature conservation and sustainable lifestyles.

The services provided by natural ecosystems, categorized as: (1) provisioning services in their creation of oxygen, food, water, raw materials; (2) regulating services for carbon capture and sequestration, water management and waste water treatment, air purification, pollination, biological control; (3) supporting services by providing habitat for flora and fauna and maintaining genetic diversity and nutrient cycling; and (4) cultural services contributing to mental and physical health in human beings, recreation/tourism, spiritual benefits (TEEB, 2011 [15]). These ecosystem services are highly valuable yet still poorly understood and underutilized by governments and local decision-makers. The EU Green Surge Project studied 20 city positions on green infrastructure, urban ecosystem services and biodiversity, and found a gap between planning and adoption of practice, with Bristol and Barcelona standing out as the most committed to holistic implementation. Abiding by the planning principles of: (1) connectivity of (green) networks/hubs; (2) multi-functionality of ecosystem services; (3) integration with other urban systems; and (4) multi-scale of implementation, proved challenging for city authorities to fully comprehend and moreover to optimize the multi-functionality of nature's palette of services. Climate adaptation was recognized as a strategic function of green infrastructure for storm water management, yet ecosystems' cultural services for human health and wellbeing were weakly acknowledged and lesser so operationalized. The Project does not address climate action on account of encouraged sustainable behavior yet recognizes the potential impact of ecosystems services in a broader planning context (Hansen and Pauleit, 2014 [16]).

Urban ecosystem services will need to play an increasing vital role as cities grow in population size, with larger senior age cohorts, and heat up faster than any other settled topographies. The 2003 heat wave in Europe resulting in more than 70,000 deaths should be seen as an early warning of more 
severe climatic conditions to come, whereby global warming is a new public health threat (Robine et al., 2008 [17]).

In the United States, heat is the greatest weather-related cause of human death as increasing temperatures above $90^{\circ} \mathrm{F}\left(32^{\circ} \mathrm{C}\right)$, aggravate air pollution and ozone levels, resulting in greater health risks, including respiratory illness, e.g., asthma, heart attacks, particularly among urban dwellers. High GHG emissions compound temperature levels leading to forecasts of even higher U.S. summer temperatures and health concerns in coming years (Kenward et al., 2014 [18]).

Greener cities are cooler cities and increasingly more economically strategic, in their management of storm water and the urban heat island (UHI) effect, responsible for over 10 billion US dollars annually in energy costs for cooling. Although other strategies exist for reducing surface temperatures, predominately albedo coatings for roofs and walls, the multi-functionality of vegetation at the building and city scale as carbon sinks as well as provider of valuable socioeconomic benefits that cannot be matched. The use of albedo products may be more cost effective and appropriate in circumstances of spatial and structural limitations, whereby hybrid solutions may optimize results.

The Urban Heat Island (UHI) concentration of higher temperatures in built up urban environments also results in increased ozone toxicity in the air as well as damage to local water bodies. UHI can be mitigated with the installation of green roofs and other urban vegetation at building and city scale (Gorsevski, Virginia et al., 1998 [19]), Structural facade temperatures can be reduced by $1-2{ }^{\circ} \mathrm{C}$ at night and $4-8{ }^{\circ} \mathrm{C}$ during the day with additional reductions of approximately $20 \%$ in energy consumption for cooling (Katzschner, 2011 [20]) on account of green roofs. Green roofs can have significant impact in high density or central business district areas with high impervious surfaces with recorded temperature reductions averaging $7.6^{\circ} \mathrm{C}$ (Gil, 2007 [21]) and can collectively have a significant impact on a city's adaptive capacities to climate change.

However, global trends are already compromising urban ecosystems and local biodiversity health as well as societies' potential for cost effective solutions to climate change and human wellbeing (McPhearson et al. [14]. The Urban Heat Island effect has led to changes in local biodiversity with increased insect populations and greater propensity of evasive plants (Parmesan, 2006 [22]; Parmesan and Yohe 2003 [23]). Further climate change impacts on biodiversity have the potential to lead to drought effects on wetlands, variable phenology of flora and fauna, and pressures on marine habitats (Wilby and Perry, 2006 [24]; Hunt and Watkiss, 2011 [25]).

Therefore, the role of cities in natural resource management and local governance of ecosystems is all the more critical. Cities can benefit from a growing network of institutional and NGOs actors to strengthen efforts towards intra-municipal and multi-jurisdictional cooperation for preserving urban biodiversity and ecological systems (Wilkinson et al., 2013 [26]). Broader engagement with non-traditional stakeholders and managers of green spaces, such as golf courses, cemeteries, private gardens can reinforce networks and raise awareness of their importance in supporting ecological processes and contributing to climate action (Ernston et al., 2010 [27]). Strengthened social-ecological systems are necessary to generate, preserve and maintain natural ecosystems (Andersson et al., 2014 [28]) and can benefit from the availability of quantifiable data on water retention of wetlands, infiltration by rain gardens, carbon sequestration of urban parks, among others to facilitate local government planning processes and strengthen the business case for broader use of green infrastructure in development projects (Tonneijck and Bade, 2011 [29]).

\section{Green Infrastructure for Climate Impact}

Governments at the local, national and multi-lateral levels are starting to recognize the climate impact of green infrastructure (GI) policies. The European Commission in 2013, released a communication on Green Infrastructure (GI), Enhancing Europe's Natural Capital, wherein it advocates its use by member states for both climate mitigation and adaptation. Green infrastructure, as defined by the European Commission as "a strategically planned network of natural and semi-natural areas with other environmental features designed and managed so as to deliver a wide range of ecosystem services". 
The US Environment Protection Agency provides ample policy guidance and tools to local communities to encourage the implementation of GI practices with a major focus on storm water management, yet suggests integrated policies to optimize ecological as well as socioeconomic benefits. Ecosystem-based adaptation has captured the attention of the UNFCCC as a resiliency strategy.

The incorporation of green infrastructure into the built environment and urban spaces bolsters the services provided by local ecosystems and strengthens their regulating capacity to better manage heat and precipitation hazards. Urban afforestation is an effective means to address climate impacts. The US City of Baltimore has demonstrated the cost effectiveness of such policy actions by quantifying the impact of its 2.8 million trees to reduce energy costs citywide by $\$ 3.3$ million a year in addition to storing 527 tons of carbon and removing 244 metric tons of ground-level ozone annually (American Forests 2015 [30]). The American Forests organization has estimated a 1:4 cost ratio of tree investment to economic and environmental return reiterating the importance and monetary value of nature. Mature trees provide the greatest impact in the removal of particulate matter and cooling effects through deposition and transpiration, underscoring the importance of urban trees (e.g., conifers and deciduous) to reach stem diameters above $30 \mathrm{~cm}$ to improve PM10 capture (Tonneijck and Bade 2011 [29]). This has been affirmed by US Conference of Mayors with the view that tree canopy is an essential part of a city's natural infrastructure for enhanced quality of life and sustainability and an important means for carbon sequestration and climate protection.

Dar es Salaam benefits from local ecosystems with annual carbon sequestration of approximately $25 \%$ of per capita emissions, yet this service is being jeopardized through the loss of mature trees at an annual rate of $11.3 \%$ (as per 2002-2008 data). Dar es Salaam epitomizes the challenges faced by rapidly urbanizing cities (in this case $5 \%$ year), particularly in the Global South, that confront losses of farmland $(11 \%)$, green areas $(29 \%)$, and riverine territory $(60 \%)$, only to become increasingly at risk of flooding at a business as usual (BAU) trajectory (Printz et al., 2015 [31]). Durban South Africa has recognized the urgency of preserving its unique biodiversity in support of ecosystem-based adaptation and as importantly to preserve the socioeconomic basis of its communities. Various policy measures have been employed, including land acquisition for landscape connectivity, open space requirements in planning processes and zoning and taxes to enhance land conservation management (Roberts et al., 2011 [32]).

Asian cities are also challenged with preserving and maintaining their green spaces due to economic development pressures and the belief green infrastructure is a luxury, rather than a necessary for public health. Jakarta is a tragic case illustrated by its precipitous loss of green space (targets) in its master plan from initially 37\%, down to $9.6 \%$ in 2010 (Said and Mansor, 2011 [33]), in spite of hazardous air pollution. Singapore is a standout in the region for its commitment and innovation to preserve its ecosystems and biodiversity through policy measures that incentivize creative urban design and integrated building engineering, e.g., green walls, to overcome high density and land area constraints. Singapore epitomizes the biophilic city in its use of nature-based solutions for climate adaptation and mitigation with constructed wetlands and green corridors (Newman, 2011 [34]) as well as its commitment to human and ecological wellbeing with the development of the Singapore Biodiversity Index [35].

Cities that prioritize ecosystem-based adaptation (EbA) through permeable pavements, green streets, constructed wetlands, greenways among others, benefit from reduced urban flooding and improved storm water management by reducing combined sewer overflows at a cost efficacy over traditional grey infrastructure (ASLA 2012 [36]). Fairfax County Virginia USA assessed over 1000 square miles $\left(2590 \mathrm{~km}^{2}\right)$ under the Urban Tree Coverage Project (UTC) and recorded 420 square miles $\left(1088 \mathrm{~km}^{2}\right)$ of tree coveragethat generates approximately $\$ 6$ billion annually in ecosystem service benefits to address air pollution, energy conservation, and storm-water management. The Urban Tree Canopy (UTC) Project is a partnership among the Chesapeake Bay Program, the Virginia Department of Forestry (VDOF), the Virginia Geospatial Extension Program (VGEP) at Virginia Tech, and local communities with the goal to assist jurisdictions with the tools and technical assistance to assess and protect their natural capital.

Integrating ecosystems into land use and spatial planning can enhance connectivity and nature's service distribution through green corridors to the urban periphery for temperature balance. Urban 
forests and parks function as valuable carbon sinks as well as lend to storm water management and regulation of urban flooding during extreme weather events. The City of Copenhagen's efforts to fortify its parks for rainfall retention during more frequently occurring cloudbursts is an example of local leadership employing nature-based solutions for climate action.

Increasing the percentage of green space at the urban scale, both through local ecosystems preservation and use of green infrastructure, offers communities not only ecological and climatic benefits but also significant socio-economic co-benefits. Greener cities provide more ecological cultural services on account of urban parks and gardens for inhabitants to experience and reap the mental, physical and spiritual benefits contributing to improved public health. Generally, experts recommend urban green space of $20 \%-50 \%$ of total land area, while the World Health Organization (WHO) suggests minimum of $9 \mathrm{~m}^{2}$ of green space per person as a more valuable metric. Analysis by the European Environment Agency (EEA) indicates the majority (94\%) of European cities in the EU-27 have between $10 \%-38 \%$ of green space (Figure 4). As important is the equitable access and proportional distribution of green space and natural infrastructure throughout the urbanscape to optimize nature's benefits for human wellbeing, to advance environmental justice and strengthen the ecological benefits for the immediate and surrounding ecosystems.

From a climate and resource efficiency perspective, the spatial configuration of green space is particularly important to mitigate the urban heat island effect, conserve water and reduce energy consumption. Cities with a combination of high percentage of green areas, high edge density (distribution of the green space) and high patch density (number of green patches per unit area) can more effectively respond to climate extremes such as heat waves and heavy precipitation (European Environment Agency (EEA), 2015 [37]; Maimaitiyiming et al., 2014 [38]). This suggests policy and urban planning should ideally prioritize connected green corridors of critical mass rather than a multitude of fragmented green spaces. However, the total percentage of green space independently is the most impactful for climate resiliency and in practice possibly the most feasible.

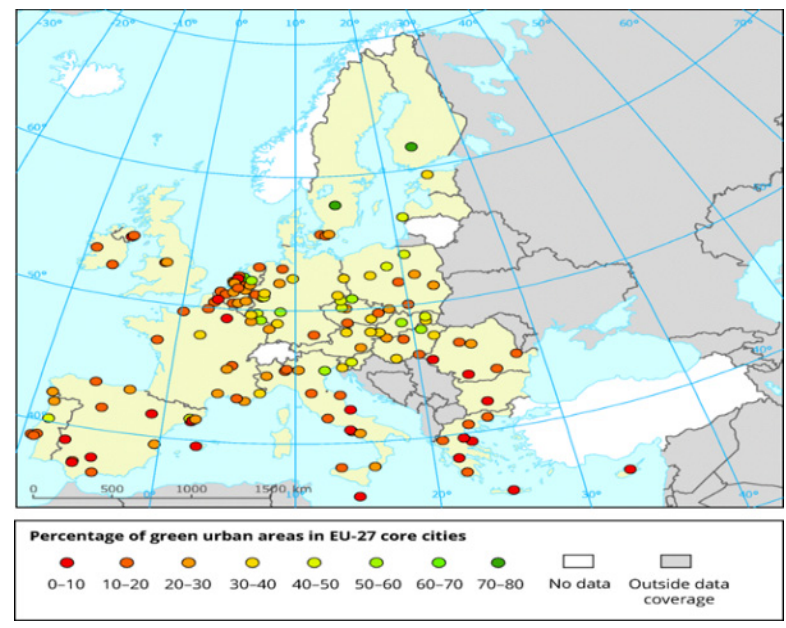

Figure 4. Green Space in EU-27 (Sorce: [39]).

\section{Biophilia and Connectedness to Nature}

The natural environment provides a stimulating context for creativity and appreciation for life (Wilson, 1984 [40]). "Healthy ecosystems are seen as shaping local identity, providing a sense of place and fostering deeper insight into nature" (Yli-Pelkonen et al., 2006 [41]), while time spent in natural areas, particularly during childhood, is a key indicator of environmental action (Chawla, 2010 [42]).

A heighten sense of environmental consciousness (or connectedness) is an essential element of the proposed climate rubric that views climate change with a broader lens beyond mitigation and adaptation issues to also include sustainable consumption and production, sustainable development, 
biodiversity conservation and sustainable lifestyles to chart the road towards global sustainability and keep within the impending two $\left(2 / 1.5^{\circ} \mathrm{C}\right)$ degree tipping point. A temperature increase of $2{ }^{\circ} \mathrm{C}$ (or $3.6^{\circ} \mathrm{F}$ ) has been determined by the world's scientists to be the point at which climate impacts, e.g., drought, sea level rise, become irreversible.

Human affinity with the natural environment and other living things is an integral part of an individual's life and our societal cultures that accentuates the concept of biophilia. This concept, put forth by Harvard biologist, Edward O. Wilson, in his 1984 book Biophilia refers to human beings' inherent relationship with nature for millennia. The Biophilia Hypothesis (1993) by Yale's social ecologist, Stephen R, Kellert, together with E.O. Wilson further elaborated the implications of biophilia and its applications to other disciplines including architecture and health care (Lysack, 2010 [43], Kellert, 1997 [44]). A recent Berlin study documented inhabitants professing a love of and demand for nature to satisfy recreational interests, aesthetic desires, educational motivations, and spiritual notions (Riechers et al., 2016 [45]).

The human species is part of the global biosphere and sources essential resources to live and build homes, create businesses and grow communities with a rooted dependency on our planet's natural capital for evolution and sustainability. Climate change amplifies the risks of human alienation from nature, all the while the exploitation of natural resources for production and economic growth paradoxically deteriorates the essence of human wellbeing. However, harnessing the services of nature to positively exploit the human-nature bond may be the most powerful means of ecological and human preservation.

In many modern societies biophilia and the recognition of nature's extensive values lays dormant. Our present day context of sprawling settlements, enslaving technology, compulsive consumption, and weak natural sciences educational curriculums account for much of this disconnection and apathy, and yet at significant socio-economic and potentially irreversible environmental costs. The paucity of teaching among American K-12 students about the benefits of nature and the human impact on the natural environment (Earth Institute, 2006 [46]) coupled with the decline in high school seniors' support of conservation (sustainable) behaviors between 1976-2005 (Wray-Lake et al., 2010, [47]), has engendered a self-serving society with little regard for life-cycle processes; and worse so, an alarming role model for developing countries.

Long term sustained climate action depends in part on re-connecting individuals and societies with the natural capital that permeates our lives. A human sense of "connectedness" to the natural environment shapes values and attitudes towards the biosphere (Schultz et al., 2004 [48]). In other literature, the theory of "urgent biophilia" suggests individuals and communities are drawn to nature and greening practices to restore human and physical states and promote healing in situ ations of disaster (Tidball, 2012 [49]), therefore it is postulated biophilia in the proactive (rather than reactive) sense may be cultivated to evoke environmentally sensitive behavior for climate resiliency, if not for human survival. Aligned with such thinking, this paper advocates greening our cities to positively exploit the ecosystem services and optimize the cultural services to catalyze inherent human biophilic tendencies. The MillionTreesNYC [50] initiative uses tree planting as a "hook" to promote environmental stewardship and support New York City's sustainability plan. Cultivating connectedness to nature may be facilitated at valued locations where individuals hold a sense of attachment and thus vested interests in their preservation. This theory of "topophilia" supports the potential of human cultural-based learning for sustainability and emphasizes that need for urban populations (Beery et al., 2015 [51]). This paper's argument is aligned with such thinking and suggests behavior change may be cultivated in a localized (urban) context, wherein nature is prevalent and reinforced by low-carbon urban infrastructure and policy that advocates sustainability and climate action. As human lives become progressively technologically dependent and urbanized, the introduction of nature into human spaces is all the more critical to abate the human-nature disconnection and minimize the tendency towards "environmental generational amnesia" (Kahn et al., 2008 [52]). 


\section{The Cost Effectiveness of Nature and Economics of Biophilia}

Advancement of the climate change agenda and employing nature-based solutions towards this aim is dependent in part on awareness of the economics.

A growing body of evidence demonstrates the valuable role and cost efficiencies of green infrastructure for both climate mitigation and adaptation (EEA 2015, [37]). The Economics of Ecosystems and Biodiversity (TEEB) global initiative has documented multiple country and urban level case studies as well as the complementarily role of nature's co-benefits for human wellbeing. Similarly, the American Society of Landscape Architects (ASLA) has cataloged green infrastructure contributions to natural systems and their confirmed support of climate measures by local authorities for their added value to traditional grey infrastructure projects. Hybrid solutions that blend nature-based applications with engineered systems may provide the optimal impact considering environmental footprints, land requirements and cost expenditures, but can vary considerably depending on the hazards and level of risk management (The Royal Society, 2014 [53]), TNC 2013 [54]). From the perspective of climate adaptation, valuations exist to make the economic and business case for nature-based solutions. The ecosystems making up Vietnam's Can Gio Reserve provide coastal storm protection and other resiliency measures for the local communities worth over US\$151 million per year (Lehman, 2015 [55]) and are more cost effective providing a holistic package of services compared to traditional grey infrastructure options.

The cost of human wellbeing is dependent on nature. A growing body of evidence demonstrates the profound positive impact the natural environment brings to the individual in learning, medical and work environments resulting in reduced stress, enhanced physiological levels, heighten mental capacities, accelerated curative and restorative properties. Studies by Kaplan (1995 [56]), Kuo et al., (1998 [57], Kuo and Sullivan ( 2001 [58]), and Frumkin (2003 [59]) as well as Roger Ulrich's seminal study "View through a Window May Influence Recovery from Surgery" (Science (1984 [60])) in which hospital patients covering from gall bladder surgery experienced reduced curative times and required less pain medication on account of simple views of trees from their room windows, underscore the powerful value of nature on the human being. The pharmaceutical industry and health care establishments have been pioneers in incorporating nature's elements into their medicines and facilities to exploit the beneficial impact on the human body and reducing medical costs. Architects and designers have started to embrace biophilic design for building construction initiated by Roger Ulrich's work in "evidence-based design", whereby quantitative data and baseline measurements have demonstrated the benefits of incorporating natural elements into building systems and interior spaces for human wellbeing. This line of work is promoting the business case for nature-based solutions across various sectors and disciplines seeking to optimize human and ecological benefits and project cost-effectiveness.

Incorporating green infrastructure and natural elements into building design and planning spaces with nature provides the means to educate individuals and acclimate societies to the socio-economic benefits and wellbeing nature can deliver throughout all aspects of human life (Kellert et al., 2011 [61]) (Table 1). It is this learning process, fueled by anecosystem's cultural services, that reinforces the local climate action rubric, with an increased propensity for environmental stewardship and sustainable behaviors. 
Table 1. Economic Benefits of Biophilic Design (source: Terrapin Bright Green, LLC (2012) [62]).

\begin{tabular}{|c|c|c|c|}
\hline Sector & Design Element & Human/Societal Benefit & Economic Benefits/Year \\
\hline Business/Office & Views of Nature & $\begin{array}{l}\text { Increased productivity; } \\
\text { reduced stress }\end{array}$ & $\$ 3.6$ million/employer \\
\hline $\begin{array}{l}\text { Medical-Hospitals-Health } \\
\text { Care }\end{array}$ & Views of Nature & $\begin{array}{l}\text { Reduced hospital stays } \\
\text { after surgery; restoration } \\
\text { of physiological/mental } \\
\text { states }\end{array}$ & $\$ 93,324,031 /$ year (industry savings) \\
\hline Education & Daylighting & $\begin{array}{l}\text { Heighten cognitive } \\
\text { capacities }\end{array}$ & $\begin{array}{l}7 \%-26 \% \text { improved test scores (The Alliance } \\
\text { for Excellent Education ( } 2007 \text { [63]) } \\
\text { estimates that if the students who had } \\
\text { dropped out of the class of } 2007 \text { had } \\
\text { graduated high school, the national } \\
\text { economy would have benefited from } \\
\text { an additional } \$ 329 \text { billion in income over } \\
\text { their lifetimes.) }\end{array}$ \\
\hline Real Estate, residential & $\begin{array}{l}\text { Access to park } \\
(500 \mathrm{~m})\end{array}$ & $\begin{array}{l}\text { Restoration of } \\
\text { physiological and mental } \\
\text { states; leisure, recreation, } \\
\text { relaxation }\end{array}$ & $\begin{array}{l}5 \% \text { premium in residential prices; } \\
\$ 2200 / \text { person saving to health care } \\
\text { industry to address obesity }\end{array}$ \\
\hline Retail & Daylighting & Positive environment & $40 \%$ increased sales \\
\hline Criminal Justice & $\begin{array}{l}\text { Views/simulations } \\
\text { to/of nature }\end{array}$ & $\begin{array}{l}\text { Reduced aggression, } \\
\text { stress and violence }\end{array}$ & $\begin{array}{l}52 \% \text { fewer felonies (of public housing } \\
\text { residents); approx. } \$ 162,200 \text { savings/yr } \\
\text { by State (Illinois) }\end{array}$ \\
\hline
\end{tabular}

\section{Behavioral Change towards Climate Action}

Behavioral change is a function of human habits and conscious decision-making, and in the case of environmental action, reinforced by awareness, accessibility, affordability, technologies, social norms, and biophilia (Kurz et al., 2015 [64]; Stieninger, 2013 [65]; Santiago Fink, 2011 [7]). Changing individual and societal behavior towards climate action depends upon both upstream (macro level) and downstream (individual) interventions. Social psychologists and social practice experts both acknowledge the importance of context in shaping behavior (Kurz et al., 2015 [64]). Context in the form of regulation and policies as well the biophysical and built environments are fundamental in guiding individual actions and, because of their macro/meso level implications, engaging societies towards collective impact (of behavior) towards climate action. Social environmental learning promoted by local leadership, information dissemination, community-based social marketing and fiscal incentives can cultivate social norms and sustainable behaviors (McKenzie-Mohr, Doug and Smith, William, 1999 [66]) and may influence political decision-making towards economic instruments such as carbon pricing to further advance climate solutions (World Bank, 2015 [67]). The urban context, defined by its morphology, biodiversity, mobility choices and built infrastructure, impacts inhabitants on a daily basis. Cities that offer its citizenry a choice architecture that promotes connectivity of urban systems and services, coupled with green corridors and buttressed by low-carbon modes of mobility for walking, bicycling, bus rapid transit (BRT) and rail, are better positioned to foster sustainable behaviors and lifestyles as evidenced further below in Table 2. In the context of increasing urbanization, environments without nature pose even greater challenges to promote environmental awareness, ecological conservation and sustainable practices (Riechers et al., 2016 [45]). The time is ripe for local authorities and city planners to amplify nature and its equitable accessibility in urban environments, while optimizing (cultural) ecosystem services, to strengthen the ecological-social interconnections paramount in fostering climate action.

Transportation accessibility is a cornerstone of a sustainable urban environment and dictates the viability of a sustainable lifestyle on the basis that transport emissions representthe fastest growing sector and are expected to double by 2035 (Dulac, 2013 [68]; IPCC, 2014 [6]) In today's rapidly urbanizing world, true commitment to climate change mandates a low-carbon trajectory for 
mobility infrastructure (Nakamuraand Hayashi, 2014 [69]) to optimize spatial layout and systems configuration with a socio-economic and environmental lens. Policy interventions are understood in the behavioral literature as context destabilizers that create windows of opportunity to disrupt habitual, business as usual practices, largely based on attitudes, values, and norms, and introduce deliberate decision-making on the part of the individual. Changing ingrained personal habits, for example to use public transit, is more probable during periods of routine change, e.g., new employment, re-location, (Kurz et al., 2015 [64]). This coincides with the author's climate action rubric which underscores the importance of pre-empted urban investments in low-carbon transport infrastructure and city (and metropolitan) level incentives, e.g., transit subsidies, to encourage and guide behavior change. Similarly, public investment in pedestrian infrastructure and access to green areas is necessary to cultivate, broad-based public support for the general protection and governance of ecosystems (Pyle, 1993 [70], Millennium Ecosystem Assessment, 2005 [71], Miller, 2005 [72]).

The policy and regulatory context cannot be avoided and provides the essential framework for equitable and effective climate action implementation without which a tragedy of the commons is the current reality and inevitable future without essential behavior change. The macro level context must also be exemplified by institutional action that demonstrates government and public actors leading by example, a vital lesson learned during the UK government's behavioral change strategy (Fudge and Peters, 2011 [73]). Political leadership to introduce a congestion tax in various European cities has reduced the number of automobiles on the road, by $12 \%$ in the case of Gothenburg Sweden. In Ljubljana, its car-free city center has heightened the quality of life and led to the re-election of its visionary yet practical mayor. Leading by public example is a powerful means of social learning and promoter of sustainable behavior at the individual and institutional levels (Reed et al., 2010 [74]; Wray-Lake et al., 2010 [47])

Education is an equally important driver of sustainability, particularly at the primary and secondary school levels, for cultivating future generations to respect and live in balance with the natural environment (Lysack, 2010 [43]). However, at present, less than 25\% of children globally complete secondary school (UN 2012 [2] undermining the resiliency potential of our present and future societies.

The consumer market is an aggressive driver of behavioral change. Growing global consumerism is amongst the root causes of natural resource depletion and contributors toclimate instability. The demand for goods will only increase as Brazil, Russia, India and China (the BRICS) and other emerging economies continue to grow and develop. Therefore, a complementary global challenge is to re-direct production processes towards nature-based sustainable practices that embrace resource efficiency, life cycle assessments and biomimicry to decouple economic development from environmental degradation and mitigate climate impact. The UK experience recognized the need for a concerted commitment among all parties, involving government, industry/private sector and consumers/households to effectuate sustained change towards low-carbon lifestyles (Fudge and Peters, 2011 [73]).

Channeling the consumer market towards sustainable/green commodities offers a tremendous opportunity to nudge behavior to support climate action. A 2015 10,000-person sample survey indicated the consumers of the world's nine largest economies are willing to support sustainability and opt for companies engaged in sustainable production practices and committed to corporate social responsibility. More optimistic is the trend among consumers of the acknowledgement of their personal responsibility for sustainable action and willingness to compromise ownership or quality in support of ecological and social purposes (Cone Communications, 2015 [75]). The Cone survey complements a global survey $(n=62)$ conducted by the author, wherein a sense of personal commitment to take climate/environmental action was highly recorded, both through participating in a planning process and willingness to pay for urban ecosystems for environmental protection. The author survey's purpose was stakeholder input for the Urban Climate Change Researchers Network (UCCRN) ARC2-3 2015-6 publication for the Paris COP21, which explored the current public awareness of the nature-climate link for the chapter on Urban Ecosystems and Biodiversity. The indications of personal 
commitment are positive rallying points for further research to guide development of policy, fiscal and planning instruments for behavior change towards climate action.

\section{Role of Technology in Shaping Sustainable Behavior}

In present day, the role technology and social media play in influencing (environmental) behavior cannot be under estimated and could easily be a separate paper. In support of the current argument, suffice to say technology's capacities, e.g., participatory sensing tools, applications, among others, can allow planners and researchers to better understand the impact of the cultural ecosystem services on the individual and society (MacKerron and Mourato, 2013 [76]). In addition it facilitates communication by cities to engage their citizenry in a shared sense of purpose in shaping a sustainable and resilient city through positive messaging of Mother Nature's free benefits for ecological and human wellbeing. An attitudinal trend among American high school seniors, whereby technology is highly seen as the solution to environmental problems, interestingly reinforcing their environmental commitment (Wray-Lake et al., 2010 [47]) as well as an understanding of how the technology-driven shared/collaborative economy can advance climate action, offers valuable research promise.

\section{Climate Impact on Wellbeing and Quality of Life}

Health is a sensitive tipping point and key determinate of quality of life. As climate change becomes increasingly viewed in the context of public health, the quality of life in cities will be an important indicator of their prosperity. Environmental conditions and infrastructure services have taken high importance among the various city rating systems. Such urban metrics influence corporate investment and human resource decisions and can have serious implications for local governments. Cities that do not meet basic health standards run the risk of losing foreign direct investment and the presence of transnational corporations that monitor the work environments of their employees. Pollution, public services, transportation, and the natural environment are among the rating factors used by Mercer's Location Evaluation and Quality of Living Reports. Similarly, the Economist Liveability Ranking weights environment and cultural aspects as $25 \%$ of their total score, with climate and temperature as prominent contributing indicators. Infrastructure and its services contribute $20 \%$ with public transportation being a key parameter. The Siemens Green City Index categorizes cities based upon resource consumption, ecological supporting behaviors and carbon emissions per capita. The world's top ranked cities for quality of life provide the institutions, infrastructure facilities and ecological conditions that are conducive to economic growth and illustrative of high levels of sustainable societal behavior (Table 2). Most are intermediate size cities with a compact urban form supported by an integrated network of public transport infrastructure and ample amount of green space that create the basis for a harmonious and healthy quality of life (Bieri, 2013 [77]). Further investigation would reveal the advantages of European urban morphologies and energy sources that are reflected in lower $\mathrm{CO}_{2}$ emissions and higher sustainable behavior indicators attributable in large part to public policy shifts and low-carbon urban infrastructure investments after the 1970s energy crisis; however, this is beyond the scope of this paper.

Public health concerns can serve as a common denominator to unite differences across the climate agenda and engage population groups in finding common ground for sustainable climate action. Galvanizing broader political and public support lies in raising awareness of the climate-health linkage and the multiplicity of benefits nature-based solutions can contribute to creating low-carbon well-planned communities for healthy and sustainable quality of life. An urban environment that supports a balanced co-existence between nature and its built infrastructure provides the upstream context to influence human behavior and encourage sustainable lifestyles that underpin long-term climate stability. 
Table 2. Quality of life and environmental indicators—overview of select cities.

\begin{tabular}{|c|c|c|c|c|c|c|c|}
\hline City & $\begin{array}{l}\text { City Rankings of Quality of Life by: } \\
\text {-Mercer's City Quality of Living } 2015 \text { (global) } \\
\text {-Economist Liveability Rankings } 2014 \text { (global) } \\
\text {-Siemens European Green City Index } 2009\end{array}$ & Pop. (2015) & $\begin{array}{l}\mathrm{CO}_{2} \text { Tonnes } \\
\text { per Capita }\end{array}$ & $\begin{array}{l}\text { Green Space: \% } \\
\text { of Total Area }\end{array}$ & $\begin{array}{l}\text { Sustainable Behaviors of } \\
\text { Citizens: \% of Walking, } \\
\text { Cycling or Taking Public } \\
\text { Transport to Work }\end{array}$ & $\begin{array}{l}\text { Sustainable } \\
\text { Behavior of City: } \\
\text { \% Recycled } \\
\text { Municipal Waste }\end{array}$ & $\begin{array}{l}\text { PM10/PM2.5 } \\
\text { (EEA) ** }\end{array}$ \\
\hline Vienna & $\begin{array}{l}\text { \#1 Mercer (since 2011) } \\
\text { \#2 Economist } \\
\text { \#4 Siemens }\end{array}$ & $1.8 \mathrm{~m}$ & 5.19 & $27.20 \%$ & $68 \%$ & $33.35 \%$ & $27 / 19$ \\
\hline Zurich & $\begin{array}{l}\text { \#2 Mercer } \\
\text { \#6 Siemens }\end{array}$ & $377 \mathrm{~K}$ & $\begin{array}{l}3.70 \\
\text { (estimated) }\end{array}$ & $(24 \%)$ & $62 \%$ & $34 \%$ & $20 / 14$ \\
\hline Vancouver & $\begin{array}{l}\text { \#5 Mercer } \\
\text { \#3 Economist } \\
\text { \#2 Siemens (in North America) }\end{array}$ & $603 \mathrm{~K}$ & 4.2 & $11.7 \%$ & $24.5 \%$ & $60 \%$ (est.) & 4.9 PM2.5+ \\
\hline Copenhagen & $\begin{array}{l}\text { \#9 Mercer } \\
\text { \#1 Siemens }\end{array}$ & $1.2 \mathrm{~m}$ & 5.38 & $17.50 \%$ & $68 \%$ & $23.61 \%$ & $12 / 17$ \\
\hline Melbourne & \#1 Economist (since 2011) & $4.4 \mathrm{~m}$ & $17.7^{*}$ & $22 \%$ (tree canopy) & $22 \%$ & $62 \%$ & 14.8 PM2.5\# \\
\hline
\end{tabular}

Source: author; Data sets referenced: Siemens Green Index, Mercer, European Commission; Cities listed were ranked in at least two of the three indices in the top 10, with the exception of Melbourne that was included due to its longevity ranked \#1 by the Economist Global Liveability Rankings; * [78]; + [79]; \# [80]; ** EEA = European Environment Agency; PM = particulate matter in micrometers. 


\section{Conclusion and Recommendations}

We are at a cross roads in human development. Years of anthropogenic exploitation of Mother Nature are manifesting in significant costs to human lives, economic assets and natural capital. Global population is nearing nine billion, with urban populations projected at 6.3 billion by 2050 (Gouldson et al. [81] 2015), and exerting prohibitive pressures on the natural environment while jeopardizing the basic resources individuals and societies need to survive. The globally adopted UN Sustainable Development Goals (SDGS) are an imperative call to action for governments and societies to pursue a sustainable trajectory in how we plan, source and live our lives within planetary boundaries. In the aftermath of the Paris Conference of the Parties (COP21), national governments will be obliged to transpose the climate agreements into policies and programs that incentivize timely implementation to preserve our natural ecosystems, and in doing so, harness their services to lay the road for closing the emissions gap and safeguarding human prosperity.

Sustainable cities, represented by SDG \#11, encapsulate many if not all the other development goals in a microcosm that offers amongst the best opportunities to advance in parallel climate action and global sustainability. These international agendas intersect in urban environments that house the world's population agglomerations, critical infrastructure and economic hubs, and therefore represent the ideal economies of scale to cultivate the societal behavior change essential for long lasting climate stability.

Cities can harness the power of its citizens and natural capital for the urgency needed to expedite the incremental multi-lateral climate processes. Local policy makers can shape the regulatory context through planning and investment decisions that prioritize low-carbon/impact infrastructure and nature-based solutions as integral elements of a local climate action rubric to meet adaptation and mitigation needs. In turn nature's invaluable ecosystems services (co-benefits) can foster the betterment of local socio-economic conditions and lay the foundation for sustainable behaviors. Environmental awareness and action is in part the result of contact with the natural environment in everyday life (Chawla, 2010 [42]); promoting it at scale will require the greening of our cities, public spaces, and built environments, wherein urban planning will need to play an instrumental role in embedding green infrastructure principles into development practices (Benedict, Mark, McMahon, and Edward, 2001 [82]).

Nature-based solutions provide the essential services to contribute substantially to mitigate carbon emissions and enhance adaptive capacities. Simultaneously, nature provides the ecosystem cultural services to enhance human health and well-being. In a policy context that supports greener cities heighten environmental consciousness and stewardship is cultivated and can potentially promote sustainable behavior change on account of awaken biophila. Limited empirical evidence and the challenges of measuring biophilia have necessitated an exploratory review of the association of biophilia and climate action. It is therefore introduced in the broader context illustrated in the local climate rubric with the understanding that individual and societal behaviors are a function of multiple factors but human sustainability solely one-Mother Nature.

\section{Policy and Research Recommendations}

A forward thinking and supportive policy context is fundamental to advancing the global climate and sustainability goals. Cities can be instrumental in contributing to both agendas.

The following policy recommendations are put forth to better position cities and optimize their contributions. Some specific recommendations for cities are found in Appendix (Table A1).

- $\quad$ Strengthen national level policy engagement with sub-national and city governments, promoting vertical integration, on the climate change and sustainable development agendas.

- Allow access to sub-national governments and non-state actor partnerships to international financing and capacity building mechanisms. 
- Support cross-sector and multi-disciplinary programming at the national levels that fund and facilitate implementation of integration of urban systems planning, infrastructure development and operations at the sub-national and city levels.

- Mandate environmental education curriculums at all academic levels, starting with primary school through university; incentivize learning institutions to become models of sustainability by optimizing structural space for renewable energy, storm water management, energy efficiency, urban agriculture, and local knowledge sharing

- Support cities in data collection, monitoring, reporting and verification (MRV) of socio-economic and ecological indicators

- Incorporate natural ecosystem valuations and impact assessments into development projects;

- Monetize the value of urban ecosystems services as part of a local awareness raising and call to action campaign

- Enforce sustainable land use planning and integrated systems design, adopting local ordinances to promote renewable energy, green infrastructure, inter-connected multi-modal transport infrastructure, net zero energy buildings

- Optimize the restoration, equitable distribution and governance of urban ecosystems and green spaces; support networks and encourage participation of non-traditional actors; support the creation of green jobs and small businesses for the maintenance of green spaces.

- Provide incentives for nature-based urban innovations and biomimicry research that meet the needs of local communities and sectors

Better understanding the drivers of behavioral change for climate action is a continuous process in light of changing demographic trends, political landscapes and technological advancements. Additional research is needed to learn how to effectively catalyze biophilia at the individual and societal levels and channel it towards tangible actions that culminate in sustainable lifestyles. The following research recommendations are suggested to further explore the human-nature nexus for the benefit of advancing environmental preservation, climate action and sustainable human development:

- Understand the effects of different types of (public) green space on the individual and potential impact of cultural ecosystem services to foster behavior change in support of climate and sustainable actions.

- Explore the level of personal responsibility towards global sustainability and willingness to pay or compromise in support of ecological and socio-economic aims.

- Investigate the impact of biophilic design on building end-users with the aim to understand the degree of environmental awareness and sustainable behavior and its spillover, if any, to other aspects of an individual's life.

- Record citizen understanding of urban ecosystems and their services in select cities to gage a willingness to pay for nature-based and low-carbon/impact solutions for addressing climate change and sustainability concerns.

- Better understand the degree of personal connectedness to nature and what that means for the individual in terms of their daily actions and lifestyle choices.

- Further investigate the climate-health relationship to understand the impacts of intersecting agendas on individual and societal behavior towards climate action.

Acknowledgments: To the perseverance of humans and nature.

Conflicts of Interest: The author declares no conflict of interest. 


\section{Appendix}

Table A1. Climate action rubric (and accelerator)—priorities for local governments.

\begin{tabular}{|c|c|c|c|}
\hline Sector & Strategies/Actions & Climate Action Outcomes and Benefits & City Resources \\
\hline \multicolumn{4}{|c|}{ Urban Planning and Policy } \\
\hline & $\begin{array}{l}\text { Land use and spatial planning for } \\
\text { compact development; mixed-uses; } \\
\text { transit oriented development (TOD); } \\
\text { urban systems integration; connectivity } \\
\text { of services; higher densities; street } \\
\text { design; zero waste; sustainable transport; } \\
\text { renewable energy Prioritize brown field } \\
\text { development Public lighting: change to } \\
\text { LEDs/ CFLs, sensor lighting }\end{array}$ & $\begin{array}{l}\text { Mitigation of energy demand and } \\
\text { reduced GHGs; Adaptation and } \\
\text { resiliency; Mitigation of energy use; } \\
\text { reduced resource (land) consumption }\end{array}$ & $\begin{array}{l}\text { http://www.sfclimateaction.org/ } \\
\text { https://nextcity.org/daily/entry/dublin-ban-cars-city- } \\
\text { center-city-council--vote } \\
\text { http://baltimoredevelopment.com/for-business/ } \\
\text { assistance-programs-tax-credits/brownfield-tax-credit/ } \\
\text { http:// corporativo.codensa.com.co/EN/PRENSA/ } \\
\text { COMUNICADOS/Pages/CODENSAandUaespcompleted } \\
\text { Bogot\%C3\%A1'sFirstLEDPublicLightingSystem.aspx } \\
\text { http://www.bogotahumana.gov.co/article/localidad- } \\
\text { kennedy-recibe-nuevas-luminarias-p\%C3\%BAblicas-en- } \\
\text { el-sector-plaza-am\%C3\%A9ricas }\end{array}$ \\
\hline \multicolumn{4}{|l|}{ Urban Ecosystems } \\
\hline & $\begin{array}{l}\text { Use of green infrastructure; install green } \\
\text { roofs (and facades), plant street trees, } \\
\text { protect and maintain urban parks and } \\
\text { forests; create pocket pockets and green } \\
\text { corridors; Eco-systems based adaptation } \\
\text { with green infrastructure and hybrid } \\
\text { systems; Ecosystems conservation } \\
\text { and management }\end{array}$ & $\begin{array}{l}\text { Mitigation of energy demand and } \\
\text { reduced GHGs; Adaptation: storm water } \\
\text { management; Behavior Change; } \\
\text { Sustainable Lifestyles Biodiversity } \\
\text { conservation Food security Water and } \\
\text { air purification }\end{array}$ & $\begin{array}{l}\text { http://www.teebweb.org/publication/teeb-manual-for- } \\
\text { cities-ecosystem-services-in-urban-management/ } \\
\text { http://water.epa.gov/infrastructure/greeninfrastructure/ } \\
\text { gi_funding.cfm http:/ / www.gicinc.org/ }\end{array}$ \\
\hline
\end{tabular}


Table A1. Cont.

\begin{tabular}{|c|c|c|c|}
\hline Sector & Strategies/Actions & Climate Action Outcomes and Benefits & City Resources \\
\hline \multicolumn{4}{|c|}{ Low-Carbon/Impact Development } \\
\hline Transport & $\begin{array}{l}\text { Low-carbon/hybrid multi-modal } \\
\text { transportation: public transit (metro, } \\
\text { light rail, BRT, bus circulators); bike } \\
\text { share, car to go, technology apps (Uber, } \\
\text { Lyft); pedestrian, biking infrastructure }\end{array}$ & Mitigation of GHGsPublic Health & $\begin{array}{l}\text { https://www.itdp.org/our-cities-ourselves-principles-for- } \\
\text { transport-in-urban-life/ http://www.godcgo.com/ }\end{array}$ \\
\hline Buildings & $\begin{array}{l}\text { Retrofit public inventories for high } \\
\text { energy efficiency of residential, } \\
\text { commercial, industrial buildings; trade } \\
\text { in out dated appliances; installation of } \\
\text { green roofs and green alleys: green } \\
\text { building codes Green municipal } \\
\text { government operations and office spaces; }\end{array}$ & $\begin{array}{l}\text { Mitigation of GHGs Adaptation and } \\
\text { Resiliency Food security }\end{array}$ & $\begin{array}{l}\text { http://www.chicagoclimateaction.org/ } \\
\text { http://www.nyc.gov/html/gbee/html/plan/plan.shtml }\end{array}$ \\
\hline Waste & $\begin{array}{l}5 \text { Rs, re/up-cycling, } \\
\text { http:// thegreeningofwestford.com/ } \\
\text { 2014/04/5-rs-refuse-reduce-reuse- } \\
\text { repurpose-recycle.html Waste to } \\
\text { energy models }\end{array}$ & $\begin{array}{l}\text { Mitigation of GHGs, Green Economy, } \\
\text { Behavior/Lifestyle Change }\end{array}$ & $\begin{array}{l}\text { http://www.wienenergie.at/eportal2/ep/channelView.do/ } \\
\text { pageTypeId/72164/channelId/-51715 }\end{array}$ \\
\hline
\end{tabular}

Source: author with references from: CDP Cities 2012, [83]; US Conference of Mayors, [84]. 


\section{References}

1. Statement at the Interactive Dialogue on Harmony with Nature I General Assembly of the United Nations. Available online: http://www.un.org/pga/270415_statement-interactive-dialogue-on-harmony-with-nature/ (accessed on 3 June 2015).

2. United Nations Secretary-General's High-level Panel on Global Sustainability. Resilient People, Resilient Planet: A Future Worth Choosing; United Nations: New York, NY, USA, 2012.

3. Swilling, M.; Robinson, B.; Marvin, S.; Hodson, M. City-Level Decoupling: Urban Resource Flows and the Governance of Infrastructure Transitions. A Report of the Working Group on Cities of the International Resource Panel; UNEP: Nairobi, Kenya, 2013; ISBN: ISBN: 978-92-807-3298-6.

4. $\quad$ Erickson, P.; Tempest, K. Keeping Cities Green: Avoiding Carbon Lock-in Due to Urban Development; Stockholm Environment Institute: Stockholm, Sweden, 2015.

5. Advancing Climate Ambition: Cities as Partners in Global Climate Action. Available online: http:/ / unenvoy.mikebloomberg.com/assets/SEI_C40_Summary_FullReport.pdf (accessed on 1 July 2015).

6. Climate Change 2014, Synthesis Report; Intergovernmental Panel on Climate Change: Geneva, Switzerland, 2015.

7. Santiago Fink, H. Promoting behavioral change towards lower energy consumption in the building sector. Innov. Eur. J. Soc. Sci. Res. 2011, 24, 7-26. [CrossRef]

8. Erickson, P.; Tempest, K. Advancing Climate Ambition: How City-Scale Actions Can Contribute to Global Climate Goals; Stockholm Environment Institute: Stockholm, Sweden, 2014.

9. Message from the Mayor. Available online: http://www.nyc.gov/html/builttolast/pages/home/home.shtml (accessed on 3 June 2015).

10. Chesapeake Bay Foundation. Project Summary Report-Green Roof Demonstration Project October 2003-September 2008. Available online: http://doee.dc.gov/sites/default/files/dc/sites/ddoe/publication/ attachments/Green\%20Roofs\%20Report\%2003-08.pdf (accessed 15 September 2015).

11. Manville, M.; Shoup, D. People, Parking and Cities. J. Urban Plan. Dev. 2005. [CrossRef]

12. Heck, Stefan; Rogers, Matt; Carroll, Paul. Resource Revolution: How to Capture the Biggest Business Opportunity in a Century; Houghton Mifflin Harcourt: Boston, MA, USA, 2014.

13. Beatley, T. Biophilic Cities: Integrating Nature into Urban Design and Planning; Island Press: Washington, DC, USA, 2011.

14. Timon, M.; Karki, M.; Herzog, C.; Santiago Fink, H.; Abbadie, L.; Kremer, P.; Clark, C.M.; Palmer, M.I.; Perini, K. Urban Ecosystems and Biodiversity. In Urban Climate Change Research Network Second Assessment Report on Climate Change in Cities (ARC3-2); Rozensweig, C., Solecki, B., Eds.; Cambridge University Press: Cambridge, UK, 2016.

15. Andre, M.; Berghoefer, A. The Economics of Ecosystems Eamp; Biodiversity: TEEB Manual for Cities: Ecosystem Services in Urban Management; TEEB: Geneva, Switzerland, 2011.

16. Reike, H.; Pauleit, S. From Multifunctionality to Multiple Ecosystem Services? A Conceptual Framework for Multifunctionality in Green Infrastructure Planning for Urban Areas. Ambio 2014, 43, 516-529. [CrossRef]

17. Robine, J.M.; Cheung, S.L.; Le Roy, S.; Van Oyen, H.; Griffiths, C.; Michel, J.P.; Herrmann, F.R. Death toll exceeded 70,000 in Europe during the summer of 2003. C R Biol. 2008, 331, 171-178. [CrossRef] [PubMed]

18. Kenward, A.; Yawitz, D.; Sanford, T.; Wang, R. Summer in the City: Hot and Getting Hotter; Climate Central: Princeton, NJ, USA, 2014. Available online: http:/ / www.climatecentral.org/ (accessed on 20 November 2015).

19. Gorsevski, V.; Haider, T.; Quattrochi, D.; Luvall, J. Air Pollution Prevention through Urban Heat Island Mitigation: An Update on the Urban Heat Island Pilot Project; U.S. Environmental Protection Agency: Washington, DC, USA, 1998. Available online: http://wwwghcc.msfc.nasa.gov/uhipp/epa_doc.pdf (accessed on 15 November 2015).

20. Katzschner, L. Urban Climate Maps, Presentation at Brandenburg University of Technology; University of Kassel: Kassel, Germany, 2011.

21. Gill, S.E.; Handley, J.F.; Ennos, A.R.; Pauleit, S. Adapting Cities for Climate Change: The Role of the Green Infrastructure. Built Environ. 2007, 33, 115-133. [CrossRef]

22. Parmesan, C. Ecological and Evolutionary Responses to Recent Climate Change. Annu. Rev. Ecol. Evolut. Syst. 2006, 37, 637-669. [CrossRef]

23. Parmesan, C.; Yohe, Gary. A globally coherent fingerprint of climate change impacts across natural systems. Nature 2003, 421, 37-42. [CrossRef] [PubMed] 
24. Wilby, L.R.; Perry, G.L.W. Climate change, biodiversity and the urban environment: A critical review based on London, UK. Progress Phys. Geogr. 2006, 30, 73-98. [CrossRef]

25. Alistair, H.; Watkiss, P. Climate change impacts and adaptation in cities: A review of the literature. Clim. Chang. 2010, 104, 13-49.

26. Wilkinson, C.; Sendstad, M.; Parnell, S.; Schewenius, M. Urban Governance of Biodiversity and Ecosystem Services. In Urbanization, Biodiversity and Ecosystem Services. Challenges and Opportunities; Springer: Berlin, Germany, 2013; pp. 539-587.

27. Ernstson, H.; Barthel, S.; Andersson, E.; Borgström, S.T. Scale-crossing brokers and network governance of urban ecosystem services: The case of Stockholm. Ecol. Soc. 2010, 15. Article 28. Available online: http:/ / www.ecologyandsociety.org/vol15/iss4/art28/ (accessed on 15 May 2015).

28. Andersson, E.; Barthel, S.; Borgström, S.; Colding, J.; Elmqvist, T.; Folke, C.; Gren, Å. Reconnecting cities to the biosphere: Stewardship of green infrastructure and urban ecosystem services. Ambio 2014, 43, 445-453. [CrossRef] [PubMed]

29. Tonneijck, A.; Bade, T. Modelling the Benefits of Urban Forests for Sustainable Management, ELCA Research Workshop Green City Europe-For a Better Life in European Cities. Available online: http:/ / www.elca.info/en/elca-research-workshop-2011.aspx (accessed on 21 July 2015).

30. American Forests, Ecological Design, Urban Places, and the Culture of Sustainability. Available online: http:/ / www.americanforests.org/what-we-do/what-we-do-urban-forests (accessed on 16 June 2015).

31. Printz, A.; Kibassa, D.; Pauleit, S.; Renner, F.; Buchta, K.; Shemdoe, R.S.; Lindley, S. The role of green infrastructure for adapting African cities to climate change: Key findings on urban ecosystems and strategic urban planning. In Proceeding of the Research Driving Innovation: Strengthening the Science-Policy Interface in African Local Governments, Durban, South Africa, 7-11 September 2015.

32. Roberts, D.; Diederichs, N.; Douwes, E.; Govender, N.; Mcinnes, A.; Mclean, C.; O’Donoghue, S.; Spires, M. Exploring ecosystem-based adaptation in Durban, South Africa: Learning-by-doing at the local government coal face. Int. Inst. Environ. Dev. (IIED) 2012, 24, 167-195. [CrossRef]

33. Said, I.; Mansor, M. Green Infrastructure in Cities and Towns in Southeast Asian Countries. In Proceedings of the Quest for Research, Second International Seminar on Sustainable Urban Development, Universiti Teknologi, Malaysia, 21 July 2011.

34. Newman, P. Green Urbanism and its Application to Singapore. Environ. Urban. Asia 2010, 1, 149-170. [CrossRef]

35. Chan, L.; Hillel, O.; Elmqvist, T.; Werner, P.; Holman, N.; Mader, A.; Calcaterra, E. User's Manual on the Singapore Index on Cities' Biodiversity (also known as the City Biodiversity Index). Available online: https://www.nparks.gov.sg/ /media/nparks-real-content/biodiversity/singapore-index/users-manualon-the-singapore-index-on-cities-biodiversity.ashx?la=en (accessed on 3 March 2015).

36. American Society of Landscape Architects. Banking on Green: How Green Infrastructure Saves Municipalities Money and Provides Economic Benefits Community-Wide; American Society of Landscape Architects: Washington, DC, USA, 2012.

37. European Environment Agency. Exploring Nature-Based Solutions: The Role of Green Infrastructure in Mitigating the Impacts of Weather- and Climate Change-Related Natural Hazards; EEA Technical Report No 12/2015; European Environment Agency: Copenhagen, Denmark, 2015.

38. Maimaitiyiming, M.; Ghulam, A.; Tiyip, T.; Pla, F.; Latorre-Carmona, P.; Halik, Ü.; Sawut, M.; Caetano, M. Effects of green space spatial pattern on land surface temperature: Implications for sustainable urban planning and climate change adaptation. Int. Soc. Photogram. Remote Sens. 2014, 89, 59-66. [CrossRef]

39. Percentage of Green Urban Areas in Core Cities; European Environment Agency: København, Denmark, 2015.

40. Wilson, E.O. Biophilia; Harvard University Press: Cambridge, MA, USA, 1984.

41. Yli-Pelkonen, V.; Pispa, K.; Helle, I. The role of stream ecosystems in urban planning: A case study from the stream Rekolanoja in Finland. Manag. Environ. Qual. 2006, 17, 673-688. [CrossRef]

42. Chawla, L. Life Paths into Effective Environmental Action. J. Environ. Educ. 1999, 31, 15-26. [CrossRef]

43. Lysack, M. Environmental Decline, Loss, and Biophilia: Fostering Commitment in Environmental Citizenship. J. Crit. Soc. Work 2010, 11. Article 3.

44. Kellert, S. Kinship to Mastery: Biophilia in Human Evolution and Development; Island Press: Washington, DC, USA, 1997. 
45. Riechers, M.; Barkmann, J.; Tscharntke, T. Perceptions of cultural ecosystem services from urban green. Ecosyst. Serv. 2016, 17, 33-39. [CrossRef]

46. The Earth Institute Columbia University. Study Shows Lack of National Consensus on Teaching K-12 Students about Human-Environmental Impacts. Available online: http: / / www.earthinstitute.columbia.edu/ news/2006/story06-29-06.php.html (accessed on 29 May 2015).

47. Wray-Lake, L.; Flanagan, C.A.; Osgood, D.W. Examining Trends in Adolescent Environmental Attitudes, Beliefs, and Behaviors across Three Decades. Environ. Behav. 2010, 42, 61-85. [CrossRef] [PubMed]

48. Schultz, P.W.; Shriver, C.; Tabanico, J.J.; Khazian, A.M. Implicit connections with nature. J. Environ. Psychol. 2004, 24, 31-42. [CrossRef]

49. Tidball, K.G. Urgent biophilia: Human-nature interactions and biological attractions in disaster resilience. Ecol. Soc. 2012, 17. [CrossRef]

50. MillionTrees NYC. Available online: http://www.milliontreesnyc.org/html/home/home.shtml (accessed on 4 October 2015).

51. Beery, T.; Jönsson, K.; Elmberg, J. From Environmental Connectedness to Sustainable Futures: Topophilia and Human Affiliation with Nature. Sustainability 2015, 7, 8837-8854. [CrossRef]

52. Kahn, P.H.; Friedman, B.; Gill, B.; Hagman, J.; Severson, R.L.; Freier, N.G.; Feldman, E.N.; Carrère, S.; Stolyar, A. A Plasma Display window?-The Shifting Baseline Problem in a Technologically Mediated Natural World. J. Environ. Psychol. 2008, 28, 192-199. [CrossRef]

53. The Royal Society. Resilience to Extreme Weather-Royal Society Science Policy Centre Report; The Royal Society: London, UK, 2014; ISBN: DES3400 ISBN: 978-1-78252-113-6.

54. The Nature Conservancy. The Case for Green Infrastructure-Joint Industry White Paper; The Nature Conservancy: Arlington, VA, USA, 2013.

55. Lehman, S. Employing Ecosystems Service Valuation Guidelines to Solve Metaphysical Riddles and Make a Case for Conservation. USAID ARCC Newsletter, 29 May 2015. Available online: http:/ /www.mekongarcc. net/blog/ (accessed on 23 July 2015).

56. Kaplan, S. Review of the biophilia hypothesis. Environment and behavior 1995, 27, 801-804. [CrossRef]

57. Kuo, F.; Bacaicoa, M.; Sullivan, W.C. Transforming inner-city neighborhoods: Trees, sense of safety, and preference. Environ. Behav. 1998, 301, 28-59. [CrossRef]

58. Kuo, F.; Sullivan, W. Aggression and violence in the inner city effects of environment via mental fatigue. Environ. Behav. 2001, 33, 543-571. [CrossRef]

59. Frumkin, H. Healthy places: Exploring the evidence. Am. J. Public Health 2003, 93, 1451-1456. [CrossRef] [PubMed]

60. Ulrich, R. A view through a window may influence recovery from surgery. Science 1984, 224, 420-421. [CrossRef] [PubMed]

61. Kellert, S.R.; Wilson, E.O. The Biophilia Hypothesis; Island Press: Washington, DC, USA, 1993.

62. The Economics of Biophilia. Available online: http://www.terrapinbrightgreen.com/report/economics-ofbiophilia/ (accesed on 4 March 2015).

63. Alliance for Excellent Education. The High Cost of High School Dropouts: What the Nation Pays for Inadequate High Schools. Available online: http:/ /all4ed.org/articles/the-high-cost-of-high-schooldropouts-alliance-analysis-pegs-cost-of-2006-dropouts-at-309-billion/ (accessed on 23 May 2015).

64. Kurz, T.; Gardner, B.; Verplanken, B.; Abraham, C. Habitual behaviors or patterns of practice? Explaining and changing repetitive climate-relevant actions. WIREs Clim. Chang. 2015, 6, 113-128. [CrossRef]

65. Petra, S. Changing Human Behavior Towards Energy Saving through Urban Planning: Creation of a New Planning Approach —Lessons Learned from Europe and North America; LAP LAMBERT Academic Publishing: Saarbrücken, Germany, 2013; ISBN: ISBN-10: 3659433993.

66. McKenzie-Mohr, D.; Smith, W. Fostering Sustainable Behavior: An Introduction to Community-Based Social Marketing (Education for Sustainability Series); New Society Publishers: Vancouver, BC, Canada, 1999.

67. Thinking Socially. World Bank World Development Report 2015: Mind, Society, and Behavior; Thinking Socially: Washington, DC, USA, 2014; pp. 42-58.

68. Dulac, J. Global Land Transport Infrastructure Requirements: Estimating Road and Railway Infrastructure Capacity and Costs to 2050; OECD: Paris, France; IEA: Paris, France, 2013.

69. Nakamura, K.; Hayashi, Y. Strategies and instruments for low-carbon urban transport: An international review on trends and effects. Transp. Policy 2014, 29, 264-274. [CrossRef] 
70. Pyle, R.M. The Thunder Tree: Lessons from an Urban Wildland; Beacon Press: Boston, MA, USA, 1993.

71. Reid, W.V.; Mooney, H.A.; Cropper, A.; Capistrano, D.; Carpenter, S.R.; Chopra, K.; Dasgupta, P.; Thomas Dietz, T.; Duraiappah, A.K.; Hassan, R.; et al. Millennium Ecosystem Assessment: Ecosystems and Human Well-Being: Synthesis; Island Press: Washington, DC, USA, 2005.

72. Miller, J.R. Biodiversity conservation and the extinction of experience. Trends Ecol. Evolut. 2005, 20, 430-434. [CrossRef] [PubMed]

73. Fudge, S.; Peters, M. Behaviour change in the UK climate change debate: An assessment of responsibility, Agency and Political dimensions. Sustainability 2011, 3, 789-808. [CrossRef]

74. Reed, M.S.; Evely, A.C.; Cundill, G.; Fazey, I.; Glass, J.; Laing, A.; Newig, J.; Parrish, B.; Prell, C.; Raymond, C.; et al. What is social learning? Available online: http://www.ecologyandsociety.org/vol15/iss4/resp1/ (accessed on 2 November 2015).

75. Cone Releases the 2015 Cone Communications/Ebiquity Global CSR Study. Cone Releases the 2015 Cone Communications /Ebiquity Global CSR Study. Available online: http:/ /www.conecomm.com/2015global-csr-study-press-release (accessed on 16 May November 2015).

76. MacKerron, G.; Mourato, S. Happiness is greater in natural environments. Glob. Environ. Chang. 2013, 23, 992-1000. [CrossRef]

77. Bieri, D.S. Are Green Cities Nice Places to Live? Examining the Link between Urban Sustainability and Quality of Life. Mich. J. Sustain. 2013, 1. [CrossRef]

78. Carbon Neutral Operations SHARE. Available online: http://www.melbourne.vic.gov.au/Sustainability / CouncilActions/Documents/zero_net_emissions_2020.pdf (accessed on 4 October 2015).

79. Environmental Trends in British Columbia 2007 Report: Graphs and Figure Data (MS Excel Files). Available online: http://www.env.gov.bc.ca/soe/archive/reports/et07/chapters/ET2007_Air_Quality_Chapter.pdf (accessed on 12 October 2015).

80. Fine Particulates (PM2.5) Air Pollution Australia. Fine Particulates (PM2.5) Air Pollution Australia. Available online: http:/ / www.lead.org.au/Lanv7n3/L73-3.html (accessed on 17 October 2015).

81. Gouldson, A.; Colenbrander, S.; Sudmant, A.; Godfrey, N.; Millward-Hopkins, J.; Fang, W.; Zhao, X. Accelerating Low-Carbon Development in the World's Cities. Contributing Paper for Seizing the Global Opportunity: Partnerships for Better Growth and a Better Climate. Available online: http://newclimate economy.report/misc/ working-papers (accessed on 28November 2015).

82. Benedict, M.A.; McMahon, E.T. Green Infrastructure: Smart Conservation for the 21st Century; The Conservation Fund: Washington, DC, USA, 2001.

83. Seven Climate Change Lessons from the Cities of Europe. Available online: https://www.cdp.net/ CDPResults/CDP-Cities-2012-European-Report.pdf (accessed on 1 March 2016).

84. US Conference of Mayors. Best Practices. Available online: http://www.usmayors.org/climateprotection/ bestpractices.htm (accessed on 1 March 2016).

(C) 2016 by the author; licensee MDPI, Basel, Switzerland. This article is an open access article distributed under the terms and conditions of the Creative Commons by Attribution (CC-BY) license (http://creativecommons.org/licenses/by/4.0/). 